\title{
Difficulties to implement a support group for HIV patients
}

\author{
Julia Artur*, Philippe Genet, Agathe Pigeon, Tahar Touarhi \\ From $16^{\text {th }}$ International Symposium on HIV and Emerging Infectious Diseases \\ Marseille, France. 24-26 March 2010
}

\section{Background}

The project was to establish a support group for HIV patients, animated by a psychologist.

Our step was to allow patients to learn how to live better with their sickness by sharing their experiments of HIV.

\section{Methods}

All the 550 patients followed in our unit were informed.

Before integrating the group the patients met the psychologist individually in order to better determine their waitings.

Seven patients were met including six finally interested for the participation in the group. Among the six, two of them finally desisted.

It had been well specified with the first group that it would take place only with the presence of at least three people and thus to inform the psychologist in case of absence.

\section{Results}

The first group took place with three participants only, the second 15 days after with three participants also, and the third (and the last in fact). The last had to take place but was cancelled for lack of participants.

\section{Discussion}

Several assumptions can be proposed to explain the failure of this project:

- the very variable request according to participants: quasi absent for some, coming more for one group of meeting being quasi in the refusal of their disease, and others, on the contrary, very petitioning to exchange on the difficulties of living with this sickness where the probable disappointment of certain participants who

\footnotetext{
* Correspondence: julia.artur@ch-argenteuil.fr
}

ch Argenteuil, Argenteuil, France came only once and note that there were difficulties to divide in-depth with others wishing to remain on surface.

- the discouragement, for some, to have moved for nothing since finding itself to two (some had not prevented of their desistance), the group did not take place.

- past lapse of time between preliminary maintenance and the effective beginning of the group, (we needed a minimum number of interested patients to start the group) and finally, the schedule which returned it non accessible to people working.

Published: 11 May 2010

doi:10.1186/1742-4690-7-S1-P162

Cite this article as: Artur et al:: Difficulties to implement a support group for HIV patients. Retrovirology 2010 7(Suppl 1):P162.
Submit your next manuscript to BioMed Central and take full advantage of:

- Convenient online submission

- Thorough peer review

- No space constraints or color figure charges

- Immediate publication on acceptance

- Inclusion in PubMed, CAS, Scopus and Google Scholar

- Research which is freely available for redistribution

Submit your manuscript at www.biomedcentral.com/submit 